\title{
High Performance Liquid Chromatography coupled to Electrospray Ionisation Mass Spectrometry method for the detection of salivary human neutrophil alpha defensins HNP1, HNP2, HNP3 and HNP4
}

Nadia Ashrafi ${ }^{\mathrm{a}}$, Cristian Lapthorn ${ }^{\mathrm{a}}$, Frank Pullen ${ }^{\mathrm{a}}$, Fernando Naclerio ${ }^{\mathrm{a}}$, and Birthe V. Nielsen ${ }^{\mathrm{a} *}$ ${ }^{\text {a}}$ Faculty of Engineering and Science, University of Greenwich, Chatham Maritime, Kent, ME4 4TB, U.K.

*corresponding author: b.v.nielsen@greenwich.ac.uk

\begin{abstract}
Human neutrophil alpha defensins are antimicrobial peptides involved in the first line of defence against invading pathogens. To develop a deeper understanding of the immune responses in relation to airway inflammation and exercise induced epithelial damage it is necessary to have a sensitive method that can detect these peptides in a saliva matrix. A selective and sensitive Liquid Chromatography Mass Spectrometry (LC-MS) method for the detection of four salivary HNP (HNP1, HNP2, HNP3 and HNP4) peptides has been developed and validated. The LC-MS responses of HNPs 1-3 were compared with the response obtained from the traditionally used enzyme-linked immunosorbent assay (ELISA) that measures the combined levels of these three defensins. The peptides were separated on a Phenomenex Kinetex ${ }^{\circledR}$ C8 column $(50 \times 3.0 \mathrm{~mm}, 2.6 \mu \mathrm{m})$ on an Agilent 1200 series HPLC system using a linear MeOH: $\mathrm{H}_{2} \mathrm{O}$ : acetic acid $(0.1 \% \mathrm{v} / \mathrm{v})$ gradient. The HPLC was coupled to a Waters Synapt G1 Electrospray Quadrupole Time of Flight mass spectrometer. A full scan range from 100-2000 m/z in the positive ion mode was used for the acquisition. The LC-MS method was linear for concentrations of HNP2 between 0.05 and $1 \mathrm{ng} / \mu \mathrm{L}$
\end{abstract}


with a LOD of $0.05 \mathrm{ng} / \mu \mathrm{L}$ and LOQ of $0.1 \mathrm{ng} / \mu \mathrm{L}$. Inter- and intra- assay precisions (\%CV) were 0.3 and $14.95 \%$, respectively. HNPs were extracted from saliva by solid-phase extraction (SPE) with a recovery of $80-91 \%$. The cross-validation data revealed no significance quantitative difference between LC-MS and ELISA $\left(\mathrm{R}^{2}=0.96\right)$ and confirms that the developed LC-MS method is a reliable method for the detection of these antimicrobial markers. However, superior selectivity in the developed LC-MS method provides a unique opportunity to assess individual alpha defensin levels in the same assay. HNP1, HNP2, HNP3 and HNP4 were evaluated in young athletes before, and up to, $2.5 \mathrm{~h}$ after an exercise intervention in order to assess if the developed LC-MS method was sensitive enough to detect rapid changes in their relative levels.

\subsection{Introduction}

Human saliva is increasingly being used for proteomic and biomarker-discovery studies due to the ease of collection and simpler workflow compared with plasma and blood. Aside from a variety of electrolytes, enzymes and antibodies (immunoglobulins), saliva contains a diverse range of antimicrobial peptides (AMPs) and proteins. Similar to other mucosal surfaces, many of these AMPs form a constitutive barrier to invading pathogens entering the oral cavity [1]. Defensins are a family of highly cross-linked, structurally homologous antimicrobial peptides. They form part of the non-specific immune system that reacts against invading pathogens. Stored in neutrophils and released into the external environment by epithelial cells, they play an important role in early host defence against various types of infections [2-5]. Human $\alpha$-defensins, one of three defensin subfamilies, consist of six members (Table 1) with four (HNPs 1-4) identified in neutrophils [3,6-8]. HNP1, HNP2 and HNP3 have identical amino acid (aa) sequences with the exception of an additional amino acid in the N-terminus of HNP1 (alanine) and HNP3 (aspartate). HNP4 consists of 33 aa with $32 \%$ sequence homology to the other three defensins $[3,6,8]$. HNPs $1-4$ have 
three $\beta$-strands and two loops created by the disulphide bridges between highly conserved cysteine residues ( 2 and 4, 3 and 5). A third disulphide bridge exists between cysteine 1 and cysteine 6. Defensins compromise $30-50 \%$ of the protein content in human azurophil granules, corresponding to $5-7 \%$ of the total cellular protein content in the neutrophils [3]. The variation of HNPs is significant with 100 fold differences between subjects, and it is therefore difficult to define a normal range for individual antimicrobial peptides present in saliva [9-10]. These peptides are often present at high local concentration, often confined to specific cells in confined positions. They are then diluted in extracellular fluids presumably leading to some disagreement in their reported values. Gardner et al (2009) estimated that the saliva concentration in healthy individuals range between $1-10 \mu \mathrm{g} \mathrm{mL}^{-1}[21]$. These levels increase in various systemic disease [11-25]. Levels of HNP4 are roughly 100 fold lower [26] than HNPs $1-3$.

Defensins are effective microbicides against both Gram-positive and Gram-negative bacteria, fungi and viruses [2-5]. In addition, the peptides have been found to be overexpressed in various tumour cell lines [27-28]. Existing studies have suggested that the antimicrobial activity of AMPs, including defensins, is attributed to their ability to interact with a variety of molecular targets, present either on the cell surface (including membranes) or within cells. The mechanism of action depends on the electrostatic interactions between the cationic peptide characteristics of the defensins and the negatively charged phospholipid components in the microbial membranes [29-31].

To date, plasma or serum levels of $\alpha$-defensins have been quantified using ELISA [11-15], RIA [16], LCUV [17-19] and LC-MS [20-25]. Goebel (2000) quantified the levels of two defensin (HNP1 and HNP2) 
in human saliva of healthy subjects by LC-ESI-MS using the extracted ion chromatogram (EIC) [20]. van den Broek (2010) validated a LC-ESI- MS method for the analysis of three $\alpha$-defensins (HNPs 1-3) in plasma and serum [25]. Cabras (2010) analysed the salivary secretory peptidome profile in children affected by type 1 diabetes, and HNP1, HNP2 and HNP4 were semi-quantified using the EIC peak area [22]. To the authors' knowledge, the only study to detect all four defensins (in conjunction with 58 other salivary proteins) was conducted by Peluso (2007) and measured HNPs 1-4 by LC-ESI-MS in ten healthy volunteers and in patients with Sjogren's syndrome [24]. They found that HNP1 level in patients were higher than in the healthy controls. However, their method was not optimised for the detection of defensins, and as proline-rich proteins (PRPs) also were detected, the likelihood for HNP ion suppression is high. An optimised method for the detection of salivary HNPs will include removal of these highly abundant proteins by for example Solid Phase Extraction (SPE). Peluso and co-workers acidified saliva samples prior to analysis by LC-MS which will not remove interfering PRPs.

HNP1-3 are traditionally measured in conjunction by ELISA due to structural similarities, making it impossible to discriminate between the three peptides. For this reason the role of HNPs 1-3, but not HNP4, are commonly investigated. Therefore, a reliable analytical method that detect classes of defensins (HNPs 1-4) in a single assay will be a valuable aid in the diagnostic and prognostics of infectious diseases affecting the airways or the oral cavity. Mass spectrometry offers this opportunity. Numerous studies have suggested that exercise induces considerable physiological change in the immune system $[32,33]$ and provides a unique opportunity to evaluate the role of stress and immunological mechanisms [33]. Therefore, assessment of HNP levels during exercise could deepen our understanding of mucosal immunity and the effect of stress on this part of the immune response mechanism. Here, we present the 
validation of an LC-ESI-MS method that allows simultaneous detection of four individual HNPs (HNP1, HNP2, HNP3 and HNP4) in human saliva. This validated method has provided an opportunity to assess individual HNP levels in athletes' saliva, in order to understand their response to exercise. A crosscorrelation of the data with the commonly used ELISA (HNPs 1-3 assay) is also included.

\subsection{Experimental}

\subsubsection{Chemicals and Reagents}

LC-MS grade water was obtained from Fisher Scientific (Dartford, UK), LC-MS grade methanol (Hipersolv Chromanorm) was obtained from VWR (Leicestershire, UK) and acetic acid ( $\geq 98 \%$ purity) from Sigma-Aldrich (Gillingham, UK).

\subsubsection{Instruments and LC-MS Experimental Conditions}

Saliva samples were analysed by LC-MS using an Agilent 1200 series HPLC from Agilent Technologies (Santa-Clara, USA) coupled to a Quadrupole Time of Flight Mass Spectrometer from Waters Synapt G1 (Manchester, UK). The saliva was separated on a Kinetex ${ }^{\circledR}$ Core Shell C8 column $(2.6 \mu \mathrm{m}, 50 \times 3.0 \mathrm{~mm})$ (Phenomenex, USA). The mobile phase compositions were A: $0.1 \%(\mathrm{v} / \mathrm{v})$ acetic acid in $\mathrm{H} 2 \mathrm{O}$ and $\mathrm{B}: 0.1 \%$ (v/v) acetic acid in $\mathrm{MeOH}$, and were delivered at a flow rate of $0.6 \mathrm{~mL} / \mathrm{min}$ with a gradient of $\mathrm{B} 2-95 \%$ over a 45 minutes: In general, Eluent B was increased from 2 to $50 \%$ over 19 minutes, followed by an increase to $95 \%$ over 2 minutes. Eluent B was maintained at $95 \%$ for 3 minutes, followed by a rapid return to the initial condition of B (2\%), which was maintained for 20 minutes for re-equilibration of the column. The injection volume was $10 \mu \mathrm{L}$. The mass spectrometer was equipped with ESI with the following settings: positive ionisation mode, capillary voltage $3.50 \mathrm{kV}$, sampling cone voltage $40.0 \mathrm{~V}$, source temperature $150^{\circ} \mathrm{C}$, desolvation temperature $500^{\circ} \mathrm{C}$, cone gas flow $100 \mathrm{~L} / \mathrm{h}$, desolvation gas flow 1200 $\mathrm{L} / \mathrm{h}$, and acquisition ranging from 100 to $2000 \mathrm{~m} / \mathrm{z}$. The identification of the salivary peptide was 
confirmed using Uniprot. EICs were used for the analysis of salivary HNPs 1-4 and the change in HNP levels resulting from exercise (post 30 and 60 mins) were calculated from the EIC peak areas of HNPs 13 ions corresponding to $[\mathrm{M}+3 \mathrm{H}]^{3+},[\mathrm{M}+4 \mathrm{H}]^{4+}$ and $[\mathrm{M}+5 \mathrm{H}]^{5+}$.

\subsubsection{Sample Collection}

The human biological samples were sourced ethically and their research use was in accord with the terms of the informed consents. Participants refrained from drinking 10 minutes and eating 2 hours prior to producing a saliva sample. Unstimulated whole saliva was collected (spitting method) at a rate of no less than $1 \mathrm{~mL} / \mathrm{min} .1 \mathrm{~g}$ of saliva was transferred into a clean tube and stored at $-80{ }^{\circ} \mathrm{C}$ until analysis. For the validation study, saliva from 1-11 participants were used.

\subsubsection{Exercise intervention}

Nineteen male and four female athletes (age: $23 \pm 2.39$ years; height: $1.7 \pm 0.1 \mathrm{~m}$; body weight: $76 \pm 11 \mathrm{~kg}$ ) participated in the study. Participants were recruited from the sports science group at the University of Greenwich, Medway. Ethical approval was obtained from the University of Greenwich Ethics Committee. Each participant performed a circuit training workout-session. After a warm-up, the participants performed a total of three circuits involving one set of each following eight resistance exercises: 1) contramovement vertical jump 2) bench press; 3) parallel back squat; 4) upright row; 5) dumbbell alternate lunges; 6) shoulder press; 7) alternate lunges; 8) abdominal crunch. Every exercise included 12 repetitions using the maximum possible load (with exception of the abdominal crunch that involved 20 repetitions per sets). A minimum rest in between exercises equal to the time required to change from one exercise to the following was permitted. Recovery between circuits was 2-3 minutes. The session was completed in about 60 min. Salivary samples were collected before and post 30 and 60 mins after completion of the exercise (total intervention time 2.5 hours). Statistical analysis (Student's T-test) was performed using 
Microsoft Excel 2013. The data is presented as the mean (\% increase) of HNPs 1-3 30 and 60 mins after exercise.

\subsubsection{Analysis of Defensins by LC-MS}

$1 \mathrm{~mL}$ of saliva was diluted with $1 \mathrm{~mL}$ of $1 \% \mathrm{v} / \mathrm{v}$ aqueous acetic acid and centrifuged (12,000 g, $10 \mathrm{mins})$. Discovery® DSC-18 (500 mg, 3 mL) SPE cartridges from Supleco (Bellefonte, PA, USA) were used to clean up the saliva samples. SPE reduces the interference from salivary PRPs resulting in a cleaner mass spectrum compared to saliva treated by acidification only (method optimisation, data not shown). In acidified samples, PRP was found to co-elute and significantly interfere with the detection of HNP1 and HNP2 even in the EIC. The SPE cartridges were conditioned $(15 \mathrm{~mL}$ of $50 \% \mathrm{v} / \mathrm{v} \mathrm{MeOH}$ in $1 \% \mathrm{v} / \mathrm{v}$ aqueous acetic acid), followed by washing ( $5 \mathrm{~mL}$ of HPLC grade water) and equilibration ( $5 \mathrm{~mL}$ of $1 \% \mathrm{v} / \mathrm{v}$ aqueous

acetic acid). The diluted saliva sample was loaded onto the cartridges at a flow rate of $1 \mathrm{~mL} \mathrm{~min}^{-1}$, the cartridges were washed (10 mL, HPLC grade water), and the peptides eluted ( $1 \mathrm{~mL}$ of $50 \% \mathrm{v} / \mathrm{v} \mathrm{MeOH}$ in $1 \%$ aqueous acetic acid). The eluents were dried in an integrated SpeedVac SPD 1010-130 (ThermoFisher, Colorado, USA). To account for losses, a quality control (QC), Leu-enkephalin $\left(0.3 \mathrm{ng} \mu \mathrm{L}^{-1}\right)$ was spiked into each saliva sample prior to SPE, and all levels were normalised according to the calculated SPE recovery.

\subsubsection{Analysis of Defensins by ELISA}

The saliva samples obtained from the 23 participants during weekly training sessions (pre, post 30 and post 60 mins of exercise) over a period of 2-6 weeks were used for the cross-validation study with LCMS data (total 210 samples). The saliva samples were centrifuged $\left(12,000 \mathrm{~g}, 10 \mathrm{mins} ; 4^{\circ} \mathrm{C}\right)$ and the supernatant diluted $(1000 \times)$ in the supplied sample dilution buffer. Each sample was analysed in duplicate with an ELISA kit (Hycult Biotech, Netherlands) according to the manufacturer's instructions. A 
calibration curve was constructed consisting of eight prepared standards; 0.15 to $10 \mathrm{ngmL}^{-1} \mathrm{HNPs}^{1-3}$. Absorbance $(450 \mathrm{~nm})$ values were interpolated from the calibration standards using a four parameter logistic curve (My Assays, Version 2015).

\subsubsection{Method validation}

\subsubsection{Linearity}

HNP2 standards $\left(0.05,0.1,0.3,0.6,0.8\right.$ and $\left.1 \mathrm{ng} \mu \mathrm{L}^{-1}\right)$ were prepared in HPLC grade water and reconstituted with the mobile phase $\left[\left(\mathrm{MeOH}+\mathrm{H}_{2} \mathrm{O}(50: 50)\right.\right.$, both with $0.1 \%$ acetic acid v/v]. The standards were analysed with LC-MS in triplicates and the signal-to-noise ratio $(\mathrm{S} / \mathrm{N})$ was plotted against concentration.

\subsubsection{Precision}

Precision of the method for saliva samples was determined by analysis of samples with endogenous concentrations of the peptides and a QC (HNP2) samples spiked after SPE at three different concentrations

(0.3 ng $\mu \mathrm{L}^{-1}, 0.6 \mathrm{ng} \mu \mathrm{L}^{-1}$ and $\left.0.8 \mathrm{ng} \mu \mathrm{L}^{-1}\right)$ with samples analysed in triplicate $(\mathrm{n}=3)$. The samples were left at room temperature and re-analysed after 24 hours. Reproducibility was calculated from the EIC (peak area) and expressed as a coefficient of variation $(\% \mathrm{CV})$.

\subsubsection{Recovery}

Extraction recovery was determined by spiking HNP2 and Leu-enkephalin into saliva at three different concentrations $\left(0.3 \mathrm{ng} \mu \mathrm{L}^{-1}, 0.6 \mathrm{ng} \mu \mathrm{L}^{-1}\right.$ and $\left.0.8 \mathrm{ng} \mu \mathrm{L}^{-1}\right)$. Both peptides were solubilised in $\mathrm{MeOH}$ : $\mathrm{H}_{2} \mathrm{O}$ (50:50). The endogenous concentrations of HNP1, HNP3 and HNP4 in these samples were also assessed and expressed as a \% CV. The extraction recovery was determined by comparing the EIC peak area of the saliva sample spiked prior to SPE with saliva samples spiked post SPE, corrected for the peak area of the endogenous peptides. 


\subsubsection{Stability}

The stability of the HNP2 standard in saliva was investigated after one month of storage. A saliva samples were split into two, and HNP2 spiked into the samples at three different concentrations $\left(0.3 \mathrm{ng} \mu \mathrm{L}^{-1}, 0.6\right.$ ng $\mu \mathrm{L}^{-1}$ and: $0.8 \mathrm{ng} \mu \mathrm{L}^{-1}$ ). The relative levels of HNP1, HNP3 and HNP4 were also assessed in these saliva samples. Following SPE, one of the sample were reconstituted in mobile phase and analysed by LC-MS $(n=3)$, and one stored as a lyophilised powder for one month $\left(-80^{\circ} \mathrm{C}\right)$. The stability was calculated from EIC (peak area) and expressed as a \%CV. The stability of the standard leu-enkaphalin in saliva was also assessed and compared with similar levels in a freshly prepared non-saliva matrix.

\subsection{Results and Discussion}

\subsubsection{Separation and detection of HNPs}

The four salivary defensins (HNPs 1-4) were successfully separated and detected by LC-MS (Figure 1). Ions at RT 19.20 min with $m / z, 861$ and 689 and 1147 (corresponding to $[\mathrm{M}+3 \mathrm{H}]^{3+},[\mathrm{M}+4 \mathrm{H}]^{4+},[\mathrm{M}+5 \mathrm{H}]$

${ }^{5+}$ ) for HNP1, RT 19.49 min with $m / z$ of 1124,843 and 674 (corresponding to $[\mathrm{M}+3 \mathrm{H}]{ }^{3+},[\mathrm{M}+4 \mathrm{H}]{ }^{4+}$, $[\mathrm{M}+5 \mathrm{H}]^{5+}$ ) for HNP2, RT 19.56 min with $\mathrm{m} / \mathrm{z}$ of 1162,872 and 698 (corresponding to [M+3H] ${ }^{3+}$, $[\mathrm{M}+4 \mathrm{H}]^{4+},[\mathrm{M}+5 \mathrm{H}]^{5+}$ ) for HNP3, and RT of 20.74 min with $\mathrm{m} / z$ of 742 and 928 (corresponding to $[\mathrm{M}+3 \mathrm{H}]^{3+},[\mathrm{M}+4 \mathrm{H}]^{4+}$ ) for HNP4 were the most intense ions in the mass spectra (Figure 2).

\subsubsection{Method validation}

\section{Linearity}

The HNP2 standard gave a linear response (EIC peak area vs concentration) in the range of 0.05 to $1 \mathrm{ng} \mu \mathrm{L}^{-1}\left(\mathrm{R}^{2}=0.99\right)$. The mean determination $(\mathrm{n}=3)$ were $10 \pm 6.7 ; 20 \pm 0.1 ; 34 \pm 0.1 ; 80 \pm 1.6 ; 108 \pm$ $3.1 ; 140 \pm 3.2\left(0.05,0.1,0.3,0.6,0.8,1 \mathrm{ng} \mu \mathrm{L}^{-1}\right.$, respectively $)$. 


\section{Precision}

The intraday \%CV for endogenous HNP1, HNP3 and HNP4 (EIC peak area response) was in the range of $0.36-5 \%$ and the interday $\% \mathrm{CV}$ was $6.4-15 \%$ (Table 2). Interday precision was established from the re-analysis of the same sample after 24 hours. The intraday \%CV of the EIC response of spiked HNP2 at three different concentrations $\left(0.3 \mathrm{ng} \mu \mathrm{L}^{-1}, 0.6 \mathrm{ng} \mu \mathrm{L}^{-1}\right.$ and $\left.0.8 \mathrm{ng} \mu \mathrm{L}^{-1}\right)$ was in the range of $0.6-3.1 \%$, while the interday $\% \mathrm{CV}$ of the response was $10.5-12.6 \%$. Overall, the intraday \%CV for HNP 1-4 (EIC peak area response) was in the range of $0-5 \%$ and the interday $\% \mathrm{CV}$ was 6-15\%. Likewise, the EIC peak area of spiked Leu-enkephalin into the saliva matrix was evaluated and the \% CV determined to be $1 \%$ (24 hours), which is within the acceptable range for repeatability (CV of <20\%) [37-38]. Encouragingly, these values are similar to reported intra- and interday precisions for HNP1, HNP2 and HNP3 in plasma (9.814.0\%, 10-19\%, LC-MS) and serum (5.6-6.7\%, 7-10\%, LC-MS) [25]. To avoid any bias, all athletes' saliva samples were analysed immediately after SPE.

\section{Stability}

The stability of the endogenous peptides HNP1, HNP3, HNP4 and HNP2 spiked into the saliva matrix at three different concentrations was assessed up to twenty-four hours at room temperature (interday precision), and after one month in storage at $-80^{\circ} \mathrm{C}$ (as a lyophilised powder following SPE) (Table 2). The peptides are considered stable when $85-115 \%$ of the initial concentration can be found. After twelve hours at room temperature, the $\% \mathrm{CV}$ (peak area, $\mathrm{PA}$ ) was in the range of $0.3-4.7 \%$ which increased to $1.7-4.4 \%$ after twenty-four hours at room temperature. This indicates that the proteins are stable at RT for at least 24 hours. However, storage for one month at $-80{ }^{\circ} \mathrm{C}$ resulted in an increase in the $\% \mathrm{CV}$ range from $9.2-19.7$ indicating that these peptides are not stable for longer period. It is well established that saliva should be stored at $-80{ }^{\circ} \mathrm{C}$ rather than at $-20{ }^{\circ} \mathrm{C}$ to slow down proteolytic activity within the sample [36]. The LC retention times did not shift significantly over the duration of 1 month (0.6-1.8\%CV). 
The HNP2 standard was stable in solution for up to 5 hours, possibly due to the ability of the HNPs to form dimers and multimers [34]. van den Broek (2010) showed examples of ion suppression by the internal standard (HD5) and recommended use of isotope-labelled internal standards for the absolute quantification of individual HNPs [25]. Due to stability issues, Leu-enkaphalin was deemed a better choice of internal standard for quality control purposes and was spiked into saliva $\left(0.3 \mathrm{ng} \mu \mathrm{L}^{-1}\right)$ prior to SPE to correct for losses of analytes during sample preparation and to assess instrument sensitivity. Leu-enkephalin has become a commonly used reference material in MS. It typically produces one type of ion $\left([\mathrm{M}+\mathrm{H}]^{+}=556.27 \mathrm{~m} / z\right)$ during ESI in the positive mode [35].

\section{Recovery}

The recovery of the standards (HNP2 and Leu-enkephalin) was determined by comparing the EIC peak areas in the saliva matrix before and after SPE (Table 3). The standards were spiked into the saliva samples at three different concentrations $\left(0.3 \mathrm{ng} \mu \mathrm{L}^{-1}, 0.6 \mathrm{ng} \mu \mathrm{L}^{-1}\right.$ and $\left.0.8 \mathrm{ng} \mu \mathrm{L}^{-1}\right)$. The recovery data revealed an acceptable recovery range of 83-92\% for HNP2 and 89-93\% for Leu-enkephalin.

\subsubsection{Correlation between LC-MS and ELISA data}

One of the objectives of this study was to compare the data obtained by LC-MS with that obtained by ELISA for the analysis of salivary HNPs. Due to the structural similarities between HNPs1-3, their combined levels are evaluated in standard ELISA. LC-MS data for these three analytes was therefore combined (mean \% increase of HNP1-3 post 30 and 60 mins after exercise). Method validation parameters (linearity, precision and recovery) for the two methods are presented in Table 4. The data reveals that there is a good correlation (Figure 3) between the LC-MS and ELISA data for the measured levels of salivary HNP1-3 $\left(n=210 ; R^{2}=0.96\right)$. Therefore, the developed LC-MS method can be considered an accurate analytical technique to measure individual HNPs 1-3 levels in saliva. It is worth noting that the 
average LC-MS response (combined increases in HNP1-3 levels post resistance exercise intervention) tended to be higher, though not significantly, than the levels determined by ELISA (Figure 2), although this could be due to the fact that the saliva samples were stored at $-80{ }^{\circ} \mathrm{C}$ for longer between collection and analysis. Though ELISA provided a higher analyte recovery (90-101\%) compared to the LC-MS method (80-91\%) and a lower limit of detection $\left(1.56 \times 10^{-4}-0.01 \mathrm{ng} \mu \mathrm{L}^{-1}\right)$ compared to LC-MS (0.05 ng $\left.\mu \mathrm{L}^{-1}\right)$, the developed method is highly selective at detecting four individual defensins and offers the potential to identify a plethora of other analytes in the same analytical run.

\subsubsection{Analysis of saliva samples from athletes}

To establish if the developed LC-MS method is sufficiently sensitive to detect individual HNPs 1-4 in male and female participants' saliva samples a pilot study was conducted. In this study, HNP1 (EIC peak area) was the most abundant peptide compared to HNP2, HNP3 and HNP4. In addition, compared to the response of HNP1, the average HNP2 response was slightly, but not significantly, lower, whereas HNP3 and HNP4 levels were similar (approximate 0.5 fold lower than HNP1). Goebel (2000) determined the levels of HNP1 and HNP2 in twenty healthy controls and reported ranges of $0.7-23 \mu \mathrm{gmL}^{-1}$ and $0.5-17$ $\mu \mathrm{gmL}^{-1}$, respectively, and noted that in healthy controls the levels of HNP1 and HNP2 varies significantly [34]. Davison (2009) reported the concentration of salivary HNP1-3 was 0.1-0.5 ngmL ${ }^{-1}$, while in this study the concentration of HNPs 1-3 was in the range of 0.130-8.165 ng mL ${ }^{-1}$ determined by ELISA. After resistance training (post 60 mins), the levels increased significantly ( $\mathrm{p}=0.016)$ ranging from $0.430-$ 13.449 $\mathrm{ngmL}^{-1}$ at $30 \mathrm{mins}$, and $0.686-40.590 \mathrm{ngmL}^{-1}$ at $60 \mathrm{~min}$ post workout $(\mathrm{p}=0.013)($ Table 5). The $2.5 \mathrm{~h}$ of resistant training resulted in extraordinary increases in the level of each individual HNP up to $400 \%$ post 60 min exercise compared to the initial levels (Figure 4). The increase in HNP levels may result from compensation within the mucosal immune system and/or an exercise-induced airway inflammation 
and epithelial damage, which may be a part of the normal stress response [21-23], however, further studies are needed to establish the underlying biological mechanism. It is yet to be determined if this increase in transient, though literature suggest so, and for how long the immune response is detectable. We are the first to show the individual responses of salivary HNPs (HNPs 1-4) induced by exercise.

\subsection{Conclusion}

An LC-MS method for the detection of four individual salivary human defensins has been developed and validated. The method meets the requirements of the ICH Q2B guidelines for the precision, linearity, and recovery for the analysis of individual HNPs in a saliva matrix [37-38]. A correlation was observed between the LC-MS and ELISA data for the analysis of salivary HNP1-3 and the developed LC-MS method can be considered an accurate analytical technique to measure individual HNPs 1-3 levels in saliva. In addition, the study confirmed that LC-MS can be used to determine the salivary levels of HNPs 1-3 with adequate sensitivity, but higher specificity, as the traditional ELISA. The disadvantage of using immunoassay for salivary HNP1-3 measurement is that the kit is expensive, lengthy and does not discriminate between the HNPs 1-3. However, unlike the LC-MS data presented in this study, ELISA provides absolute amounts. To our knowledge, there is no report in the scientific literature of any investigation that has assessed the relative level of individual HNPs 1-4 by mass spectrometry in relation to exercise; after a high intensity circuit resistance training, salivary defensins levels were observed to increase significantly.

\section{Acknowledgements}

The authors would like to thank the British Mass Spectrometry Society (BMSS) for providing the funds for the analysis of HNP1-3 by ELISA. We also like to thank participants from the University of Greenwich 
Sports Science Group, Dr. Marco Seijo-Bujia for his support and project coordination (exercise intervention), and technical support from Dr. Patricia Wright and Kelly Cooper. 


\subsection{References}

1. Bals R, Wang X, Zasloff M, Wilson JM. The peptide antibiotic LL-37/hCAP-18 is expressed in epithelia of the human lung where it has broad antimicrobial activity at the airway surface. Proceedings of the National Academy of Sciences. 1998 Aug 4;95(16):9541-6

2. Harder J, Bartels J, Christophers E, Schröder JM. A peptide antibiotic from human skin. Nature. 1997 Jun 26;387(6636):861.

3. Wilde CG, Griffith JE, Marra MN, Snable JL, Scott RW. Purification and characterization of human neutrophil peptide 4, a novel member of the defensin family. Journal of Biological Chemistry. 1989 Jul 5;264(19):11200-3.

4. Nakashima H, Yamamoto N, Masuda M, Fujii N. Defensins inhibit HIV replication in vitro. Aids. 1993 Aug 1;7(8):1129.

5. Mehlotra RK, Zimmerman PA, Weinberg A. Defensin gene variation and HIV/AIDS: a comprehensive perspective needed. Journal of leukocyte biology. 2016 May 1;99(5):687-92.

6. Klotman ME, Chang TL. Defensins in innate antiviral immunity. Nature Reviews Immunology. 2006 Jun 1;6(6):447-56.

7. Selsted ME, Szklarek D, Lehrer RI. Purification and antibacterial activity of antimicrobial peptides of rabbit granulocytes. Infection and immunity. 1984 Jul 1;45(1):150-4.

8. Selsted ME, Harwig SS, Ganz T, Schilling JW, Lehrer RI. Primary structures of three human neutrophil defensins. Journal of Clinical Investigation. 1985 Oct;76(4):1436.

9. Gorr SU. Antimicrobial peptides of the oral cavity. Periodontology 2000. 2009 Oct 1;51(1):15280.

10. Tao R, Jurevic RJ, Coulton KK, Tsutsui MT, Roberts MC, Kimball JR, Wells N, Berndt J, Dale BA. Salivary antimicrobial peptide expression and dental caries experience in children. Antimicrobial agents and chemotherapy. 2005 Sep 1;49(9):3883-8.

11. Gunes M, Gecit I, Pirincci N, Kemik AS, Purisa S, Ceylan K, Aslan M. Plasma human neutrophil proteins-1,-2, and-3 levels in patients with bladder cancer. Journal of cancer research and clinical oncology. 2013 Feb 1:1-5.

12. Davison G, Allgrove J, Gleeson M. Salivary antimicrobial peptides (LL-37 and alpha-defensins HNP1-3), antimicrobial and IgA responses to prolonged exercise. European journal of applied physiology. 2009 May 1;106(2):277-84. 
13. Gillum TL, Kuennen MR, Castillo MN, Williams NL, Jordan-Patterson AT. Exercise, but not acute sleep loss, increases salivary antimicrobial protein secretion. The Journal of Strength \& Conditioning Research. 2015 May 1;29(5):1359-66.

14. Kunz H, Bishop NC, Spielmann G, Pistillo M, Reed J, Ograjsek T, Park Y, Mehta SK, Pierson DL, Simpson RJ. Fitness level impacts salivary antimicrobial protein responses to a single bout of cycling exercise. European journal of applied physiology. 2015 May 1;115(5):1015.

15. Mumcu G, Cimilli H, Karacayli U, Inanc N, Ture-Ozdemir F, Eksioglu-Demiralp E, Ergun T, Direskeneli H. Salivary levels of antimicrobial peptides Hnp 1-3, Ll-37 and S100 in Behcet's disease. Archives of oral biology. 2012 Jun 30;57(6):642-6.

16. Yamaguchi N, Isomoto H, Mukae H, Ishimoto H, Ohnita K, Shikuwa S, Mizuta Y, Nakazato M, Kohno S. Concentrations of $\alpha$-and $\beta$-defensins in plasma of patients with inflammatory bowel disease. Inflammation Research. 2009 Apr 1;58(4):192-7.

17. Tanida T, Okamoto T, Okamoto A, Wang H, Hamada T, Ueta E, Osaki T. Decreased excretion of antimicrobial proteins and peptides in saliva of patients with oral candidiasis. Journal of oral pathology \& medicine. 2003 Nov 1;32(10):586-94.

18. Mizukawa N, Sugiyama K, Ueno T, Mishima K, Takagi S, Sugahara T. Levels of human defensin1, an antimicrobial peptide, in saliva of patients with oral inflammation. Oral Surgery, Oral Medicine, Oral Pathology, Oral Radiology, and Endodontology. 1999 May 31;87(5):539-43.

19. Küçükkolbaşı H, Küçükkolbaşı S, Dursun R, Ayyıldız F, Kara H. Determination of defensin hnp1 in human saliva of patients with oral mucosal diseases. Journal of immunoassay and immunochemistry. 2011 Oct 1;32(4):284-95.

20. Goebel C, Mackay LG, Vickers ER, Mather LE. Determination of defensin HNP-1, HNP-2, and HNP-3 in human saliva by using LC/MS. Peptides. 2000 Jun 30;21(6):757-65

21. Gardner MS, Rowland MD, Siu AY, Bundy JL, Wagener DK, Stephenson Jr JL. Comprehensive defensin assay for saliva. Analytical chemistry. 2008 Dec 15;81(2):557-66.

22. Cabras T, Pisano E, Mastinu A, Denotti G, Pusceddu PP, Inzitari R, Fanali C, Nemolato S, Castagnola M, Messana I. Alterations of the salivary secretory peptidome profile in children affected by type 1 diabetes. Molecular \& Cellular Proteomics. 2010 Oct 1;9(10):2099-108. 
23. Pisano E, Cabras T, Montaldo C, Piras V, Inzitari R, Olmi C, Castagnola M, Messana I. Peptides of human gingival crevicular fluid determined by HPLC-ESI-MS. European journal of oral sciences. 2005 Dec 1;113(6):462-8.

24. Peluso G, De Santis MA, Inzitari R, Fanali CH, Cabras TI, Messana IR, Castagnola MA, Ferraccioli GF. Proteomic study of salivary peptides and proteins in patients with Sjögren's syndrome before and after pilocarpine treatment. Arthritis \& Rheumatology. 2007 Jul $1 ; 56(7): 2216-22$.

25. Van den Broek I, Sparidans RW, Schellens JH, Beijnen JH. Validation of a quantitative assay for human neutrophil peptide-1,-2, and-3 in human plasma and serum by liquid chromatography coupled to tandem mass spectrometry. Journal of Chromatography B. 2010 May 1;878(15):108592.

26. Fu LM. The potential of human neutrophil peptides in tuberculosis therapy. The International Journal of Tuberculosis and Lung Disease. 2003 Nov 1;7(11):1027-32.

27. Droin N, Hendra JB, Ducoroy P, Solary E. Human defensins as cancer biomarkers and antitumour molecules. Journal of proteomics. 2009 Aug 20;72(6):918-27.

28. Suarez-Carmona, M., Hubert, P., Delvenne, P. and Herfs, M., 2015. Defensins:"Simple” antimicrobial peptides or broad-spectrum molecules?. Cytokine \& growth factor reviews, 26(3), pp.361-370.

29. Lehrer RI, Barton A, Daher KA, Harwig SS, Ganz T, Selsted ME. Interaction of human defensins with Escherichia coli. Mechanism of bactericidal activity. Journal of Clinical Investigation. 1989 Aug;84(2):553.

30. Wilson SS, Wiens ME, Smith JG. Antiviral mechanisms of human defensins. Journal of molecular biology. 2013 Dec 13;425(24):4965-80.

31. Segal AW. How neutrophils kill microbes. Annu. Rev. Immunol.. 2005 Apr 23;23:197-223.

32. Hoffman-Goetz L, Pedersen BK. Exercise and the immune system: a model of the stress response?. Immunology today. 1994 Aug 1;15(8):382-7.

33. Nieman DC. Exercise, infection, and immunity. International journal of sports medicine. 1994 Oct;15(S 3):S131-41.

34. Hill CP, Yee J. Crystal structure of defensin HNP-3, an amphiphilic dimer: mechanisms of membrane permeabilization. Science. 1991 Mar 22;251(5000):1481. 
35. Sztáray J, Memboeuf A, Drahos L, Vékey K. Leucine enkephalin — a mass spectrometry standard. Mass spectrometry reviews. 2011 Mar 1;30(2):298-320.

36. Schipper R, Loof A, De Groot J, Harthoorn L, Van Heerde W, Dransfield E. Salivary Protein/Peptide Profiling with SELDI-TOF-MS. Annals of the New York Academy of Sciences. 2007 Mar 1;1098(1):498-503.

37. Huber, L. Validation of Analytical Methods (2010). Agilent Technologies, 2, p.65. Available at: https://www.agilent.com/cs/library/primers/Public/5990-5140EN.pdf [Accessed 25 September 2017].

38. ICH Q2B, Validation of Analytical Procedures: Methodology, adopted in 1996, Geneva Q2B, in 2005 incorporated in Q2(R1) 
Table 1 Discovery (year, cell source and biological fluid), amino acid sequence and antimicrobial activity of human $\alpha$-defensins (HNPs 1-6) adapted from reference [6].

\begin{tabular}{|c|c|c|c|c|c|c|c|}
\hline Year & Name & Sequence & $\begin{array}{l}\text { Length } \\
\text { (AA) }\end{array}$ & $\begin{array}{l}\text { Mw* } \\
\text { (Da) }\end{array}$ & Cell sources & Biological fluid & Activity \\
\hline 1985 & HNP1 & ACYCRIPACIAGERRYGTCIYQGRLWAFCC & 30 & 3442.08 & $\begin{array}{l}\text { Neutrophils, monocytes, } \\
\text { macrophages, natural killer } \\
\text { cells, B cells and T cells }\end{array}$ & $\begin{array}{l}\text { Saliva, Plasma, Breast } \\
\text { milk, BALF, Serum, } \\
\text { Tears }\end{array}$ & $\mathrm{G}, \mathrm{V}, \mathrm{F}$ \\
\hline 1985 & HNP2 & CYCRIPACIAGERRYGTCIYQGRLWAFCC & 29 & 3371.00 & $\begin{array}{l}\text { Neutrophils, monocytes, } \\
\text { macrophages, natural killer } \\
\text { cells, B cells and T cells }\end{array}$ & $\begin{array}{l}\text { Saliva, Plasma, Breast } \\
\text { milk, BALF, Serum, } \\
\text { Tears }\end{array}$ & $\mathrm{G}, \mathrm{V}, \mathrm{F}$ \\
\hline 1985 & HNP3 & DCYCRIPACIAGERRYGTCIYQGRLWAFCC & 30 & 3486.09 & $\begin{array}{l}\text { Neutrophils, monocytes, } \\
\text { macrophages, natural killer } \\
\text { cells, B cells and T cells }\end{array}$ & $\begin{array}{l}\text { Saliva, Plasma, Breast } \\
\text { milk, BALF, Serum, } \\
\text { Tears }\end{array}$ & $\mathrm{G}, \mathrm{V}, \mathrm{F}$ \\
\hline 1989 & HNP4 & VCSCRLVFCRRTELRVGNCLIGGVSFTYCCTRV & 33 & 3709.45 & Neutrophils & $\begin{array}{l}\text { Saliva, Plasma, Breast } \\
\text { milk, BALF, Serum, } \\
\text { Tears }\end{array}$ & $\mathrm{G}, \mathrm{V}, \mathrm{F}$ \\
\hline 1992 & HD5 & ATCYCRTGRCATRESLSGVCEISGRLYRLCCR & 32 & 3582.18 & $\begin{array}{l}\text { Intestinal paneth cells and } \\
\text { vaginal epithelial cells (HD5 } \\
\text { only) }\end{array}$ & ND & $\mathrm{G}, \mathrm{V}, \mathrm{F}$ \\
\hline 1993 & HD6 & AFTCHCRRSCYSTEYSYGTCTVMGINHRFCCL & 32 & 3708.27 & Intestinal paneth cells & ND & $\mathrm{V}, \mathrm{F}$ \\
\hline
\end{tabular}

*Disulphide connectivity $\mathrm{Cys}^{2}-\mathrm{Cys}^{30}, \mathrm{Cys}^{4}-\mathrm{Cys}^{19}$, $\mathrm{Cys}^{9}-\mathrm{Cys}^{29}$ (HNP1, HNP3, HNP4), Cys ${ }^{1}-\mathrm{Cys}^{29}, \mathrm{Cys}^{3}-\mathrm{Cys}^{18}, \mathrm{Cys}^{8}-\mathrm{Cys}^{28}\left(\mathrm{HNP}^{2}\right), \mathrm{Cys}^{3}-\mathrm{Cys}^{31}, \mathrm{Cys}^{5}-$ $\mathrm{Cys}^{20}, \mathrm{Cys}^{10}-\mathrm{Cys}^{30}$ (HD5), $\mathrm{Cys}^{4}-\mathrm{Cys}^{31}$, $\mathrm{Cys}^{6}-\mathrm{Cys}^{20}$, $\mathrm{Cys}^{10}-\mathrm{Cys}^{30}$ (HD6). G = Gram positive and Gram negative bacteria; V= viruses; F= fungi; AA = Amino acid. Peptide: $\mathrm{HD}=$ human $\alpha$-defensin; HNP= human neutrophil peptide. Biological fluid: $\mathrm{BALF}=\mathrm{Bronchoalveolar} \mathrm{lavage} \mathrm{fluid;} \mathrm{ND=} \mathrm{not}$ detected. 
Table 2 Intra-and interday precision, and stability data for HNPs 1-4 in human saliva. HNP2 were spiked into the saliva samples at three different concentrations (0.3, 0.6 and $0.8 \mathrm{ng} \mu \mathrm{L}-1)$ post SPE and analysed by LC-MS $(\mathrm{n}=3)$. The intermediate precision was calculated from the EIC (peak area) and expressed as a \%CV. The endogenous relative levels of HNP1, HNP3 and HNP4 were also assessed in these samples. Samples were stored as a lyophilised powder $\left(-80^{\circ} \mathrm{C}\right)$ after SPE and reassessed after one month.

\begin{tabular}{|c|c|c|c|c|}
\hline Defensins & $\begin{array}{c}\text { Concentration } \\
(\text { ng } \mu \mathrm{L}-1)\end{array}$ & $\begin{array}{c}\text { Intraday (12 hours) } \\
\text { \% CV }\end{array}$ & $\begin{array}{c}\text { Interday ( } 24 \text { hours) } \\
\text { \% CV }\end{array}$ & $\begin{array}{c}\text { Long term stability }(-80 \circ \mathrm{C} \text {, one month) } \\
\qquad \mathrm{CV}\end{array}$ \\
\hline \multirow[t]{3}{*}{ HNP1 } & - & 4.95 & 7.81 & 10.80 \\
\hline & - & 1.22 & 9.39 & 11.36 \\
\hline & - & 1.03 & 10.75 & 13.50 \\
\hline \multirow[t]{3}{*}{ HNP2 } & 0.3 & 3.13 & 12.63 & 17.20 \\
\hline & 0.6 & 0.64 & 10.62 & 13.90 \\
\hline & 0.8 & 2.26 & 10.51 & 15.52 \\
\hline \multirow[t]{3}{*}{ HNP3 } & - & 3.67 & 14.32 & 19.73 \\
\hline & - & 2.38 & 14.36 & 15.23 \\
\hline & - & 1.94 & 13.69 & 11.40 \\
\hline \multirow[t]{3}{*}{ HNP4 } & - & 4.69 & 6.44 & 12.80 \\
\hline & - & 3.00 & 10.54 & 12.70 \\
\hline & - & 0.36 & 14.61 & 14.40 \\
\hline
\end{tabular}


Table 3 Recovery of HNP2 and Leu-enkephalin. The standards were spiked into saliva samples at three concentrations $\left(0.3,0.6\right.$ and $\left.0.8 \mathrm{ng} \mu \mathrm{L}^{-1}\right)$ prior to and after SPE and analysed by LC-MS ( $\mathrm{n}=5)$. The recovery was calculated from the EIC (peak area) and expressed as a \%CV.

\begin{tabular}{|c|c|c|c|c|}
\hline Sample & Concentration (ng $\mu \mathrm{L}-1)$ & $\begin{array}{c}\text { EIC (mean count }) \pm \\
\text { SD }\end{array}$ & $\% \mathrm{CV}$ & \% Recovery \\
\hline Saliva & - & $33 \pm 1.7$ & & - \\
\hline \multirow[t]{3}{*}{ HNP2 spiked prior to SPE } & 0.3 & $53 \pm 1.6$ & 5.15 & - \\
\hline & 0.6 & $90 \pm 0.5$ & 3.02 & - \\
\hline & 0.8 & $116 \pm 2.6$ & 0.56 & - \\
\hline \multirow[t]{3}{*}{ HNP2 spiked post SPE } & 0.3 & $58 \pm 2.6$ & 1.72 & 83 \\
\hline & 0.6 & $101 \pm 1.5$ & 2.76 & 92 \\
\hline & 0.8 & $124 \pm 0.8$ & 1.49 & 91 \\
\hline \multirow[t]{3}{*}{ Leu-enkephalin spiked prior to SPE } & 0.3 & $74 \pm 4.2$ & 0.65 & - \\
\hline & 0.6 & $111 \pm 0.8$ & 5.68 & - \\
\hline & 0.8 & $127 \pm 0.7$ & 0.72 & - \\
\hline \multirow[t]{3}{*}{ Leu-enkephalin spiked post SPE } & 0.3 & $82 \pm 1.6$ & 0.55 & 88 \\
\hline & 0.6 & $118 \pm 0.2$ & 1.95 & 94 \\
\hline & 0.8 & $136 \pm 1.5$ & 0.17 & 93 \\
\hline
\end{tabular}


Table 4 Method validation parameters for ELISA and LC-MS.

\begin{tabular}{|c|c|c|c|c|}
\hline Technique & Peptide & Linearity & $\begin{array}{l}\text { Precision }(\%) \\
\text { (Saliva Matrix) }\end{array}$ & $\begin{array}{l}\text { Recovery }(\%) \\
\text { (Saliva Matrix) }\end{array}$ \\
\hline ELISA & Averaged response from HNP1-3 & $\begin{array}{l}\text { HNP1-3 standard: } 1.56 \times 10^{-4}-0.01 \mathrm{ng} \mu \mathrm{L}^{-1} \\
\left(\mathrm{R}^{2}=0.99\right)\end{array}$ & $\begin{array}{l}\text { Interday }<2 \% \\
\text { Intraday }<5 \%\end{array}$ & $90-101 \%$ \\
\hline LC-MS & Individual HNPs 1-3 & $\begin{array}{l}\text { HNP2 standard: } 0.05-1 \mathrm{ng} \mu \mathrm{L}^{-1} \\
\left(\mathrm{R}^{2}=0.99\right)\end{array}$ & $\begin{array}{l}\text { Interday } 0-5 \% \\
\text { Intraday } 11-14.95 \%\end{array}$ & $83-92 \%$ \\
\hline
\end{tabular}


Table 5 Salivary HNP1-3 levels determined by ELISA $(n=11)$.

\begin{tabular}{|c|c|c|}
\hline Time interval & HNP1-3 ngmL $^{-\mathbf{1}}($ mean \pm std $)$ & P value \\
\hline Pre & $1.72 \pm 2.20$ & - \\
Post 30 & $3.20 \pm 3.70$ & $\mathrm{p}=0.01$ \\
Post 60 & $6.80 \pm 11.08$ & $\mathrm{p}=0.01$ \\
\hline
\end{tabular}




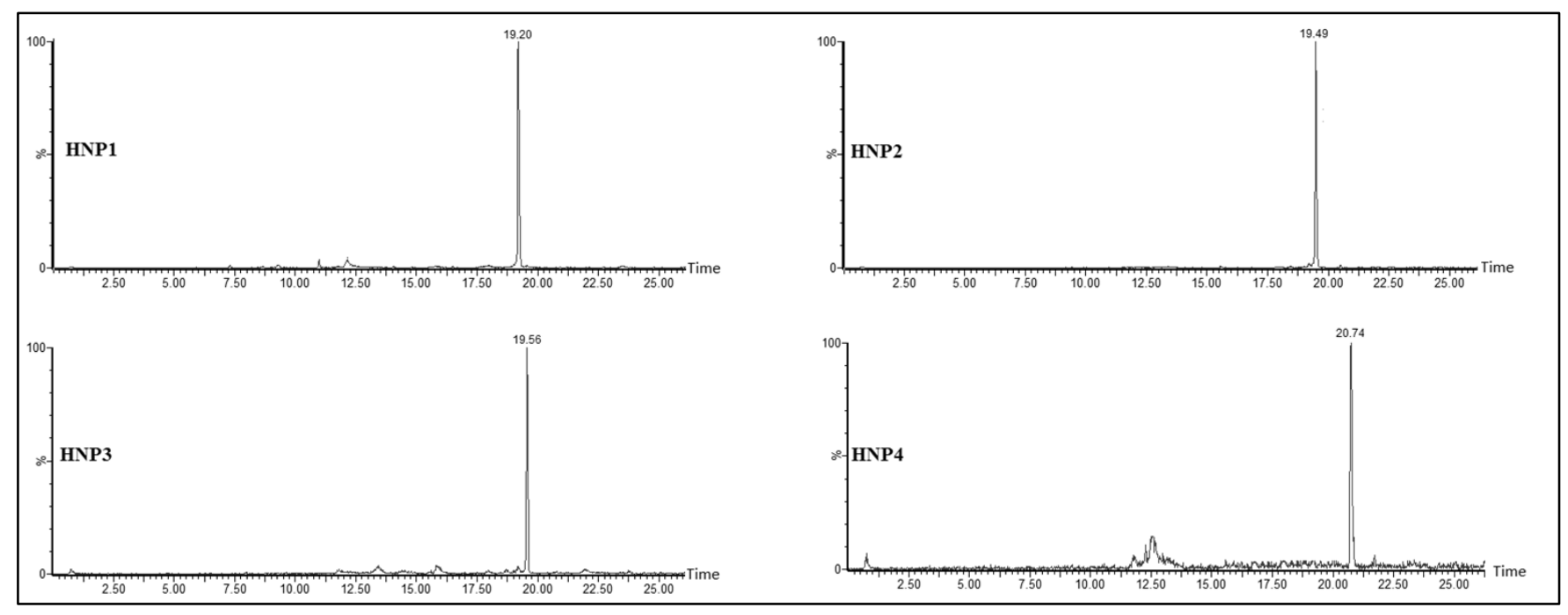

Figure 1 Extracted ion chromatogram of salivary HNP1, HNP2, HNP3 and HNP4 obtained for ions

corresponding to $[\mathrm{M}+3 \mathrm{H}]^{3+},[\mathrm{M}+4 \mathrm{H}]^{4+}$ and $[\mathrm{M}+5 \mathrm{H}]^{5+}$

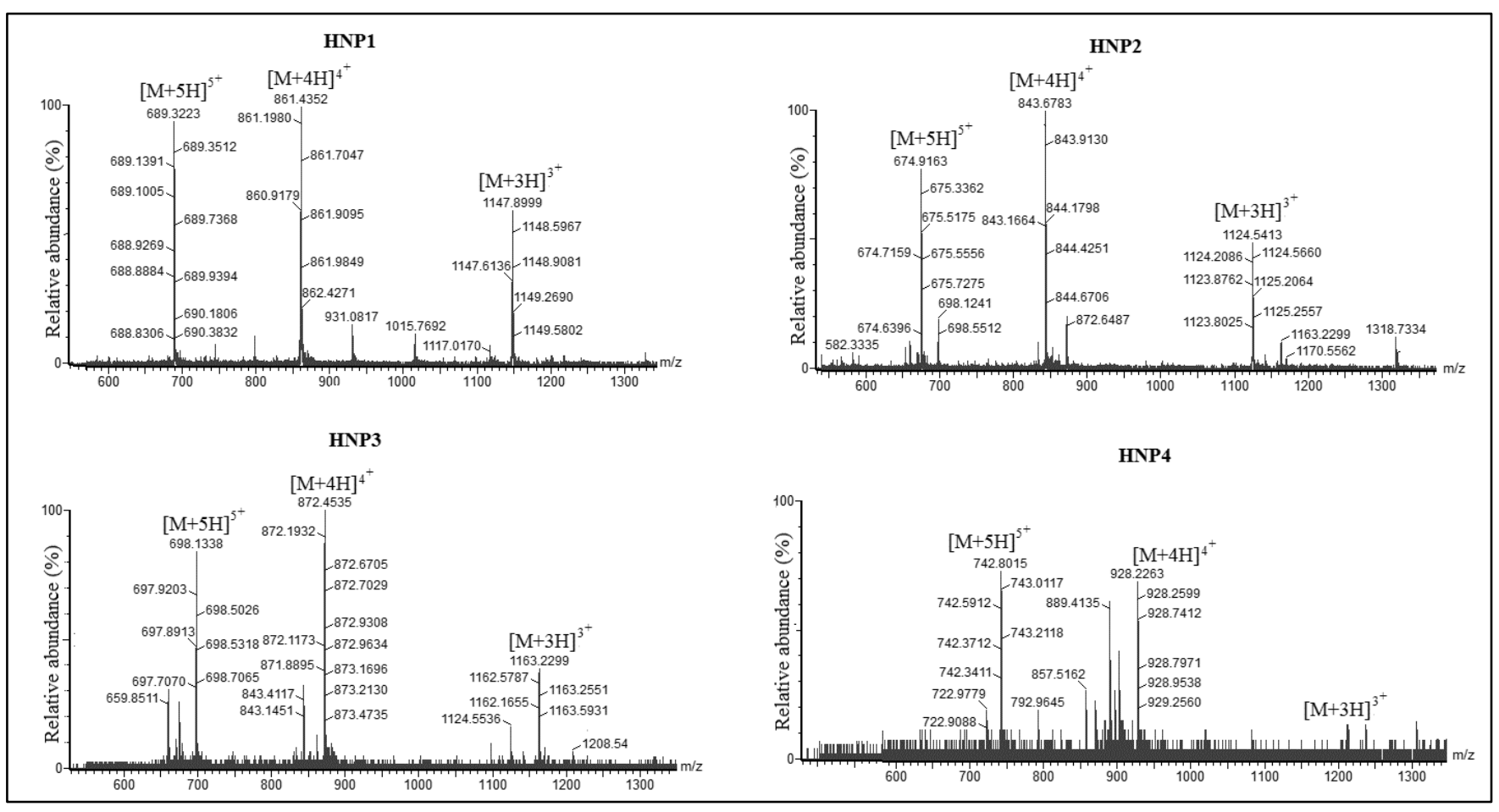

Figure 2 ESI-MS spectra of salivary HNPs 1-4 obtained for ions corresponding to $[\mathrm{M}+3 \mathrm{H}]^{3+},[\mathrm{M}+4 \mathrm{H}]^{4+}$ and $[\mathrm{M}+$ $5 \mathrm{H}]^{5+}$. 


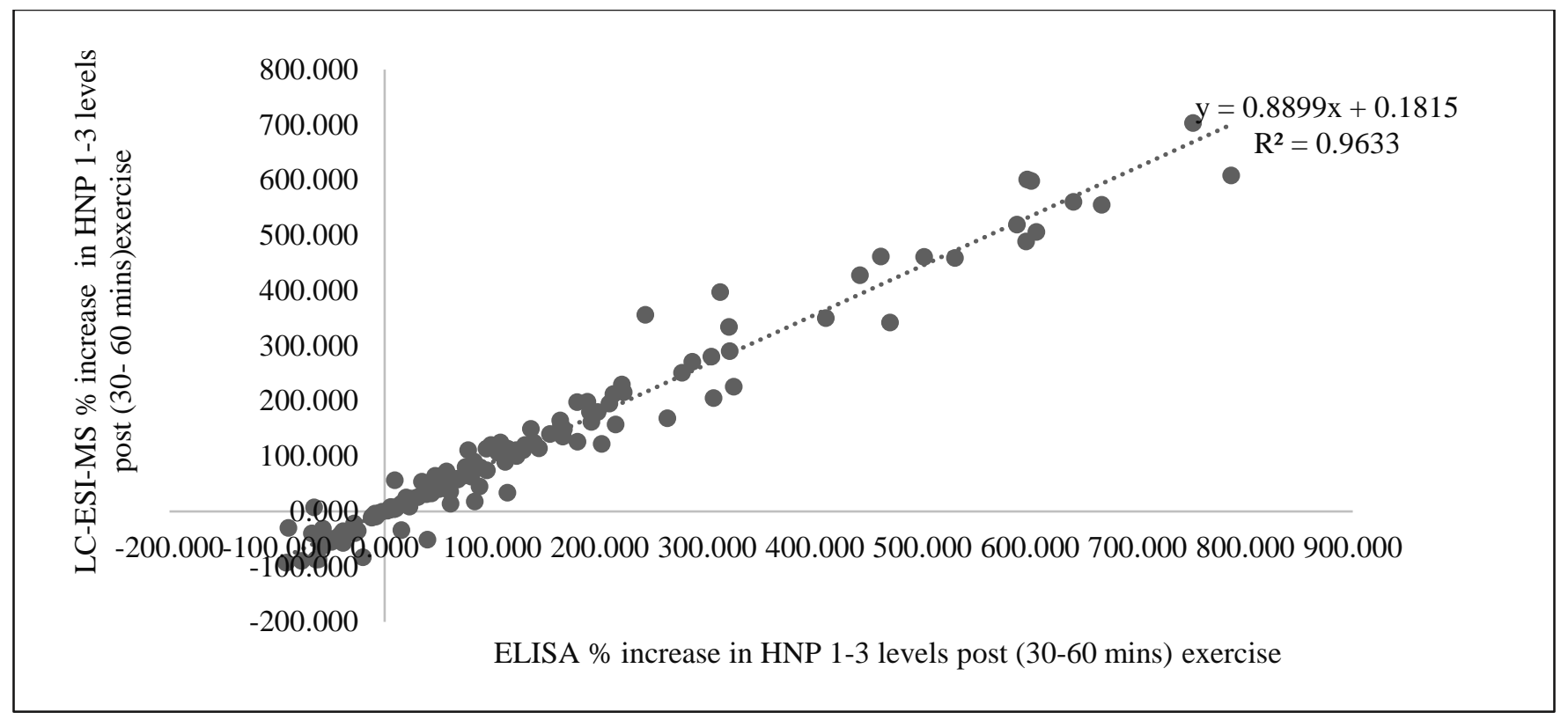

Figure 3 Correlation between LC-ESI-MS and ELISA data $(n=210)$ The data is calculated as a mean (\% increase) of HNP1-3 for post 30 and 60 minutes after exercise. The percentage increases were plotted against each other to assess the correlation between the two methods. 


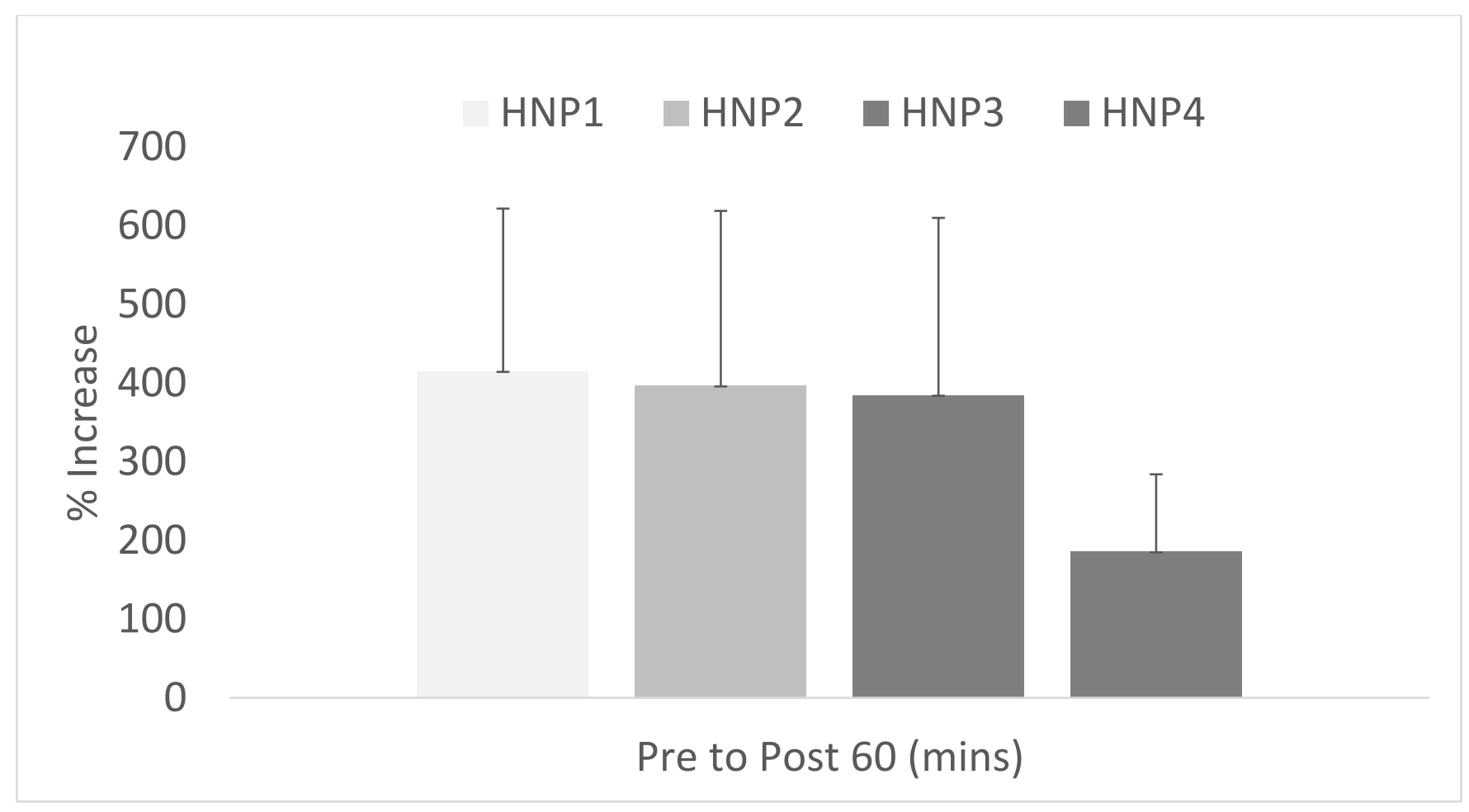

Figure 4 Percentages increases in salivary HNPs 60 mins post exercise. HNP1:415.9\%, HNP2 396.7\%, HNP3 384.8\%, and HNP4 185.8\%. The peptides were detected by LC-ESI-MS after solid phase extraction. Error bars represent standard error ( $n=11)$. All increases are significantly higher compared to levels pre exercise. 